Conference Paper

\title{
Legal Economic Literation of Digital Marketing for PKK Groups as an Inde- pendent Economic Development Efforts for Communities Affected by Covid- 19
}

\author{
Nurjanti Takarini1*, Eko Wahyudi², Anajeng Esri Edhi Mahanani² \\ 1Faculty of Economic and Business, Universitas Pembangunan Nasional "Veteran" Jawa Timur, Indonesia \\ 2 Faculty of Law, Universitas Pembangunan Nasional "Veteran" Jawa Timur, Indonesia
}

*Corresponding author

E-mail: yayannurjanti@yahoo.com

\begin{abstract}
The impact of covid-19 is not sufficiently impacting the health sector, the economic sector is equally affected. The existence of large-social restrictions, policies that scale psychological distancing cause the economic condition of the community to chaos. The scope of society that is then most affected is the people with the middle to lower economy. Surabaya, which is one of the industrial trading cities, is economically affected. The effect of the rapidly declining trading business conditions was influenced by the conditions of trading business in Indonesia and even the world. The world economy is currently on the worst curve. An increase in unemployment also occurred in the city of Surabaya. Several business businesses in Surabaya have closed down due to the impact of the Covid-19 pandemic. It is necessary then to think about efforts to get out of the big hole of the economic downturn. The community must be independent to build the family economy. This should be the focus of the economic development of the family. Increasing home-based trading is an effort that can be initiated by each family, to build an independent economy, without depending on a country that is currently also at a low economic point. Through the economic independence of the family, the hope is that it will build the country's economy slowly but surely. This dedication moves the PKK organization to encourage home-based business by utilizing information technology media. Apart from that, it also encourages people to be literate in law and economic legal policies to support the economic independence that will be built.
\end{abstract}

Keywords: Legal Economic Literature, PKK, Digital Marketing

\section{Introduction}

The Covid-19 pandemic has not ended. In Indonesia, the Covid pandemic has taken place from early March 2020 to the present, namely October 2020, and it is not yet clear when it will end. It was recorded that on October 19, 2020, there were 365,240 confirmed covid-19s and 12,617 deaths. The following is the chart data that the author took from an android-based application, an educational application data for new habitual adaptation policies:

This data is directly proportional to the condition of the Indonesian economy which is also experiencing problems. Reported from tirto.id (2020), the Central Statistics Agency (BPS) released Indonesia's economic growth figures in the second quarter of 2020. As predicted by many, Indonesia's economy contracted by -5.32 percent (year on year). Here when illustrated in graphic form:

\section{How to cite:}

Takarini, N., Wahyudi, E., \& Mahanani, A. E. E. (2021). Legal economic literation of digital marketing for PKK groups as an independent economic development efforts for communities affected by Covid-19. $5^{\text {th }}$ International Seminar of Research Month 2020. NST Proceedings. pages 297-303. doi: 10.11594/ nstp.2021.0946 

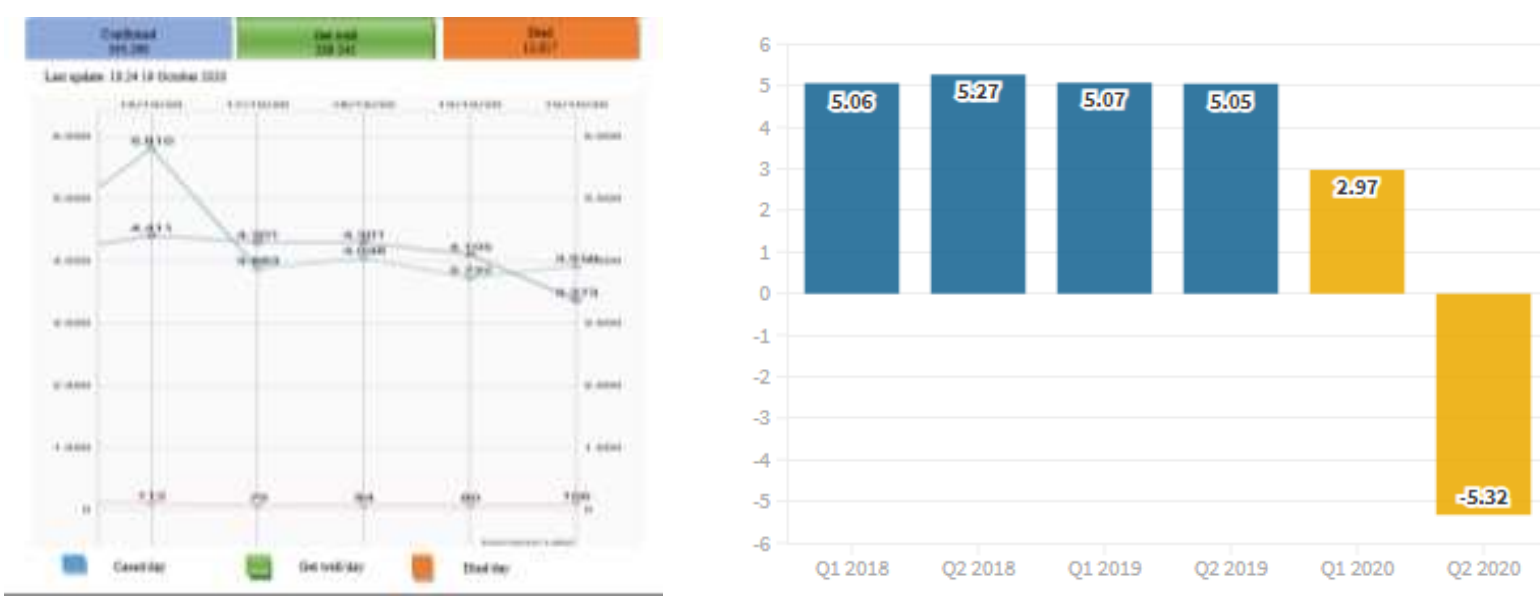

Figure 1. Data Covid-19 and Economic changes during Covid-19 (2018-2020)

The condition of a large number of victims due to the Covid-19 pandemic has prompted the government to seek immediate solutions so that the impact of Covid-19 does not further worsen the conditions for carrying out the social life of the community and nation.

This homework isn't just for the government. The impact of Covid-19 is felt by people with middle to lower economic conditions. The Ministry of Manpower (Kemnaker) noted that until July 31,2020 , the number of workers who had been dismissed or laid This negative impact in the economic sector is also very felt in the industrial city, namely Surabaya. Surabaya, which has many companies and factories with very large private employees, was also affected by the covid-19 pandemic. Many companies went out of business, and many were born unemployed.

Data on the impact of covid 19 on the occurrence of the termination of employment for many private workers must be the focus of attention of all levels of society together with the local government. Job opportunities that are difficult to open in the Pademi era and tend to experience closure, or go bankrupt, must form a new mindset, namely in droves to open jobs. A skilled, economically independent community is hope in overcoming the impact of Covid-19 in the economic sector.

Community organization groups such as the PKK should have a big role in helping to create economic independence for rural communities by providing training in skills, socializing understanding of economic independence, and so on. In this case, the extension team was interested in carrying out community service at PKK RT 005 RW 005 Manukan Kulon, related to legal economic digital marketing literacy for the PKK group as an effort to develop the independent economy of people affected by Covid-19. This digital marketing literacy is the most important part of supporting home businesses to be able to make smart use of information technology to market their products. The final result or the ultimate goal of this community service is to form community economic independence starting from the community entity unit in the smallest area, namely RT.

\section{Material and Methods}

Community service activities are carried out through enrichment of business marketing literacy, the legality of e-commerce as well as training on the use of information technology media to support e-commerce business practices. After the implementation of this education and training, the extension team will continue to monitor and open a further consultation room for the PKK RT 005 RW 005 Manukan Kulon group, to measure the development of education and training outcomes in supporting economic activity while creating economic independence during a pandemic. 


\section{Result and Discussion}

Judging from its geographic location, the location of Manukan Kulon is quite strategic, with an area of 201 hectares consisting of:

- The eastern and northern borders are bordered by Manukan Wetan,

- In the west, it is bordered by Banjar Sugihan and Lontar Villages

- Southern boundary. The composition of the population is mostly immigrants from various regions in East Java.

Based on data recorded in the sub-district, the current population of Manukan Kulon has reached more than 36 thousand people, most of whom work as civil servants, private employees, retirees, and entrepreneurs. Meanwhile, currently in Manukan Lor, which is still the area of Manukan Kulon village, a PKL center is being built, to accommodate and concentrate street vendors in one place. With the hope that the economy and the welfare of residents will be better. Meanwhile, the character of the population in Manukan Kulon is classified as heterogeneous, many of the residents are immigrants. However, this did not dampen the participation and harmony of the residents in building the village and the active role of the community in organizing.
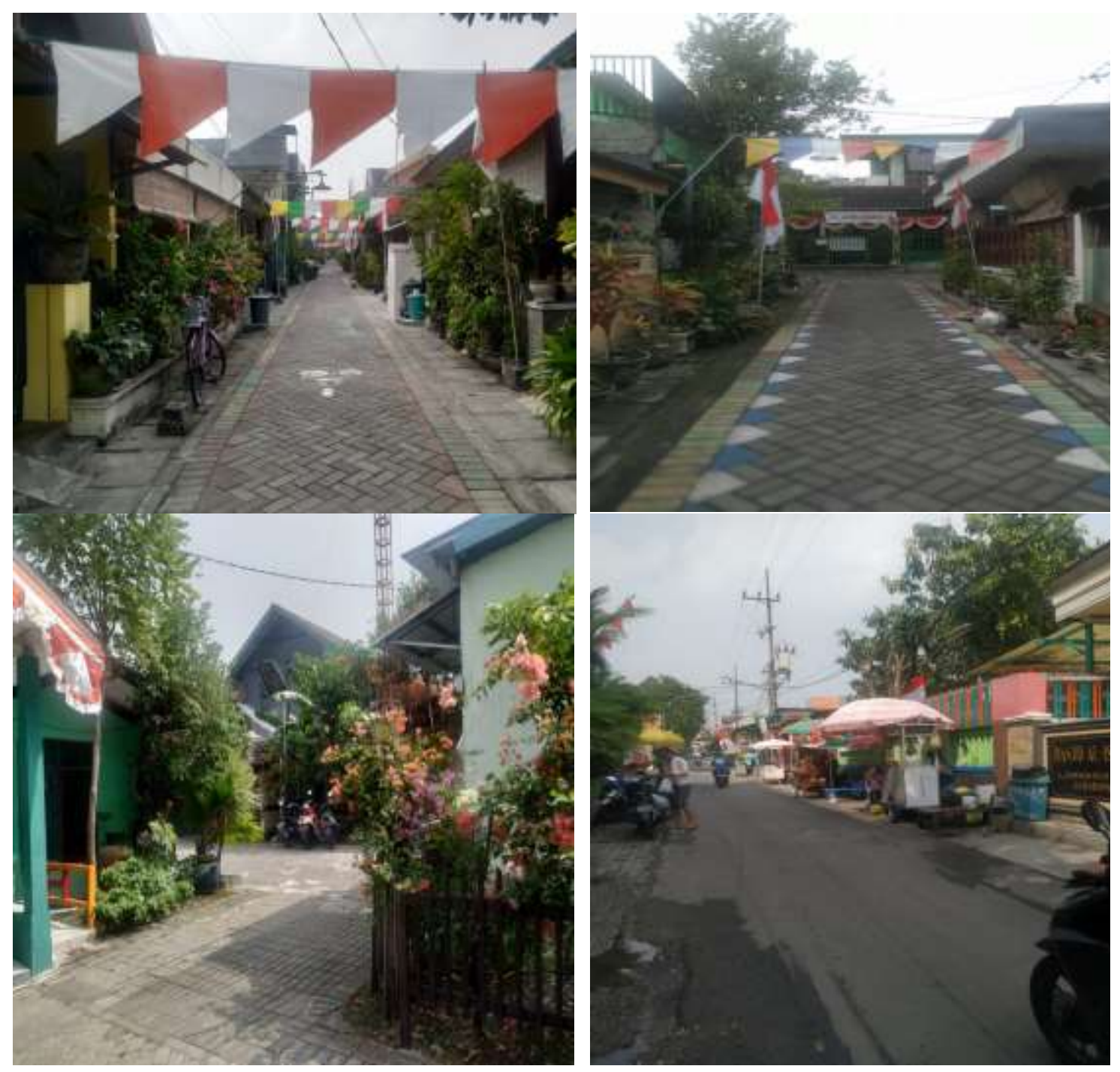

Figure 2. The profile picture of RT 005 RW 005 Manukan Kulon Village 
Seeing that there are many private and self-employed employees in this area, and a PKL center is also being built shows that the potential for a trading business or home-based business to create community economic independence is very large. This is also one of the reasons for extension workers to take the object of service in this area.

Counseling to build a rich legal digital economy literacy and digital marketing management is intended so that each production and buying and selling activity of a home business can be marketed to a wider market share. The role of community groups such as PKK is very much needed. Community groups who are engaged in building digital economy marketing literacy intelligence and legalizing digital business ventures have an important position in alleviating poverty and the lack of economic marketing knowledge in society.

The focus on providing an understanding of digital marketing is to build the spirit of PKK mothers that business is not a difficult and difficult thing. Every business venture can be marketed digitally. These efforts are the solutions offered by the team of proposers, given that internet media is ideal for expanding product marketing. In line with the research results, which state that (Lakutomo, 2014):

"There are many methods applied in the marketing of a company in various ways and these methods continue to develop into something new and innovative so that producers and consumers can meet and make transactions through certain media, including internet marketing, which makes it easier for consumers to determine and buy and sell transactions through the media is free and does not require a place or time because everyone can transact freely on the internet".

This understanding of digital marketing must be accompanied by an increase in understanding regarding the Law on Information and Electronic Transactions, including providing an understanding of the legality of business contracts, which business actors should understand and comply with even though the business is buying and selling via online (online shop). Also, an understanding will be given to the need for a business license and HaKi registration from online marketing media. The urgency of increasing understanding is in line with the research results, who said that there is a need for business permits issued by regulators (the Government and Bank Indonesia) as well as the urgency to create an IT-based MSME Development Center at the district and sub-district levels to expand the market both domestically and abroad.

The participation of community groups in creating economic independence for each (micro), indirectly also helps the government to build the macroeconomy. Sherry Arnstein in A Ladder of Citizen Participation made a scheme of 8 (eight) levels of community participation, namely as follows (Sudaryanto, 2013):

1. Citizen control/community control; at this stage, participation has reached a level where the public has the authority to decide, implement and supervise resource management;

2. Delegation of authority (delegated power); at this stage, the authority of the community is greater than that of state administrators in formulating policies;

3. Partnership (Partnership); at this stage, there is a balance of relative power between the community and the power holders to plan and make decisions together;

4. Damping(placation); at this stage people already influence policy but when it finally happens voting would seem true decision in state institutions, whereas the control of the people was not very decisive;

5. Consultation (Consultation); At this stage, the people hear their opinion and then conclude, the people have participated in making laws and regulations and state institutions have fulfilled the obligation to involve the people in making statutory regulations.

The form of community participation in creating economic independence and helping to overcome the impact of Covid-19 in the economic field lies in the concept of partnership. So that all levels of society, stakeholders, including academics in this case should jointly build a model of economic development, including through the dharma of community service. 
The following is an overview of community service activities containing legal digital economy literacy and product marketing at PKK RT 005 RW 005, Manukan Kulon Village:

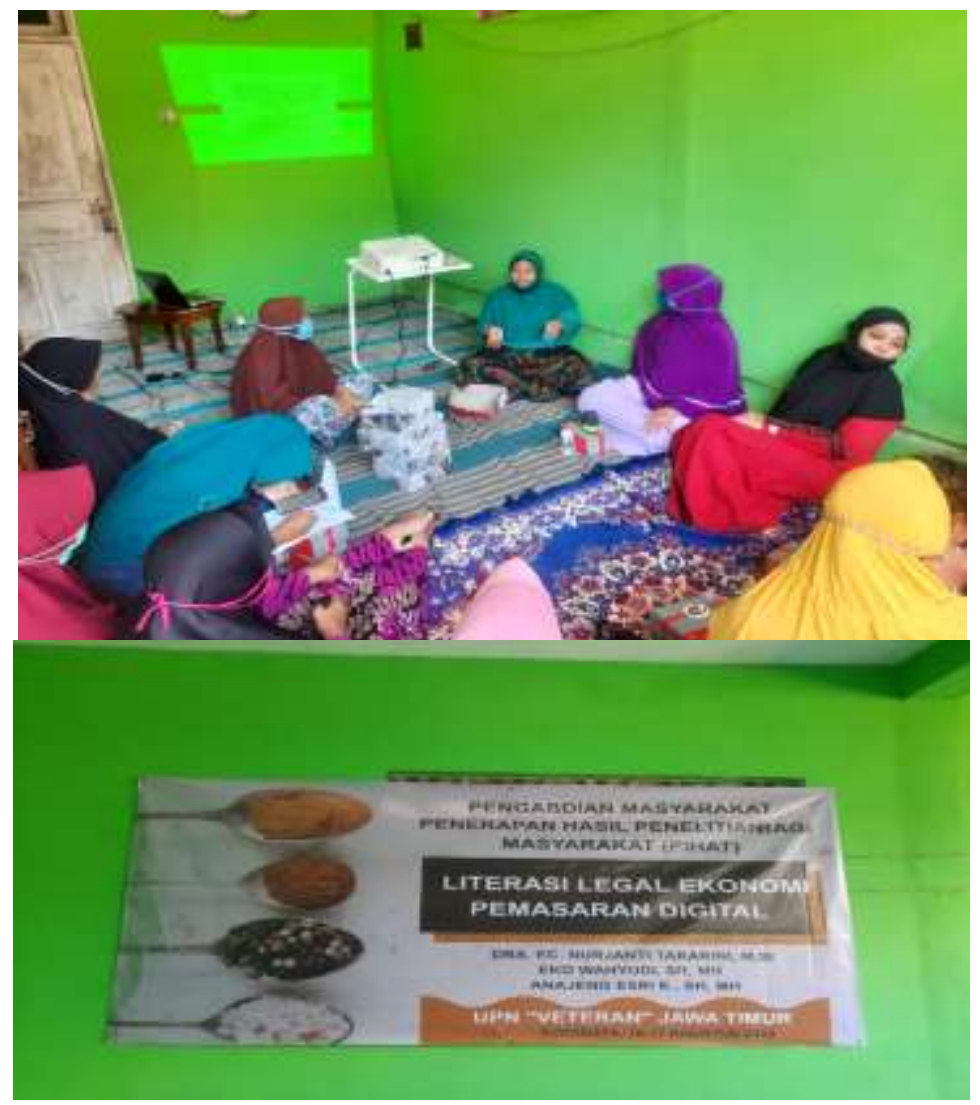

Figure 3. Community Services activity

In addition to the extension agenda, this community service also provides an online marketing platform that can be used by community groups who are running a home business, namely through the website. The use of this website includes the use of digitalization facilities.

Digitalization can be defined as a process of storing all the properties and information of text, sound, images, or multimedia in an electronic string of zero and one bits (Nico, 2007). Digitalization of marketing through this website is expected to transmit information in the form of text, sound, or images by utilizing internet transmission waves, so that product marketing will be wider. The following forms of website display are provided to be used for product marketing: 

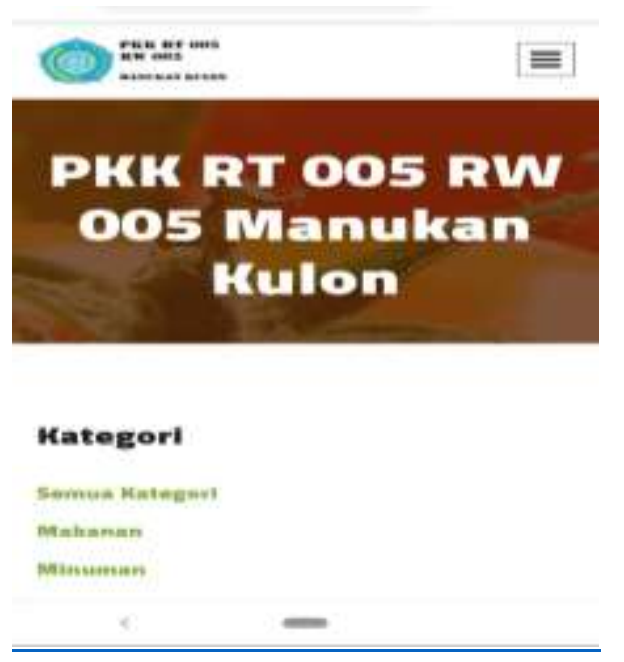

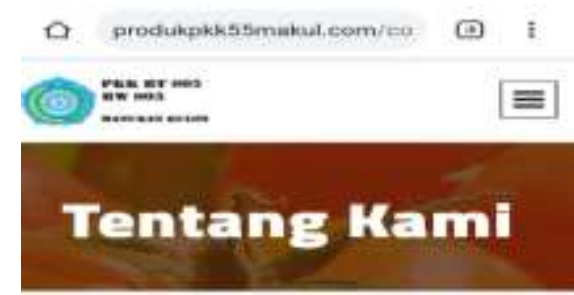

PKK RT OO5 RW OO5 Manukan Kulon

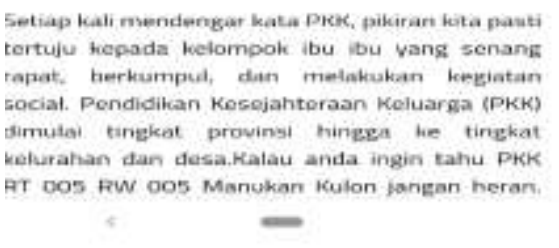

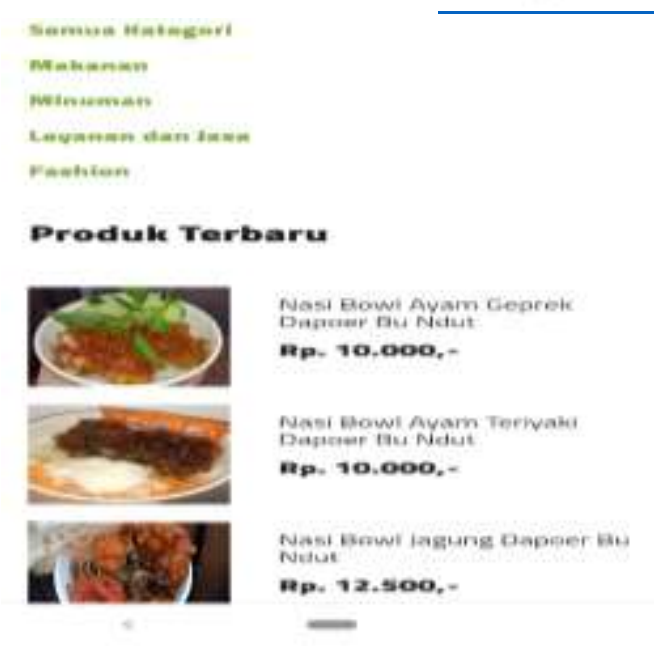

Figure 4. Community Service Online Marketing Platform

\section{Conclusion}

The results of the study can be concluded that:

1. The Covid-19 pandemic has an impact on various aspects of life, one of which is the economic aspect;

2. Many cases of Termination of Employment and the rolling of various businesses have resulted in reduced employment opportunities;

3. Community service is aimed at providing digital economic literacy, legality, and marketing through digital use, by providing an online marketing website that the community can benefit.

\section{Acknowledgment}

The author would like to thank UPN "Veteran" Jawa Timur, PKK RT 005 RW 005 Manukan Kulon, ISRM 2020's Committee

\section{References}

Kompas. (2020). Imbas corona lebih dari 3-5 juta pekerja kena PHK. Access on https://money.kompas.com/read/2020/08/04/163900726/imbas-corona-lebih-dari-3-5-juta-pekerja-kena-phk-dandirumahkan?page=all.

MPSP. (2002). Partisipasi masyarakat dalam perencanaan dan pemprograman pembangunan prasarana dan sarana perkotaan (modul peserta). Pemkot Malang Bekerjasama dengan USAID:Malang. 
Lakutomo, G. S. (2014). Analisis pemasaran terhadap bisnis online (ecommerce) dalam jaringan sosial internet. Naskah Publikasi Ilmiah. Universitas Muhamadiyah Surakarta: Surakarta,

Nico, A. (2007). Good e-government: Transparansi dan akuntabilitas publik melalui e-government. Banyumedia: Malang.

Sudaryanto. (2013). Strategi pemberdayaan UMKM menghadapi pasar bebas asean, Kemenkeu, Access on <https://www.kemenkeu.go.id/sites/default/files/strategi\%20pemberdayaan\%20umkm.pdf>.

Surabaya Blogspot. (2015). Profil desa. Access on http://beritadesasurabaya.blogspot.com/2015/01/profil-desa.html Tirto.id (2020). Bagaimana COVID-19 mengubah ekonomi Indonesia \& ASEAN?. Access on https://tirto.id/fWjv. 